\title{
SOCIO-ECONOMIC DETERMINANTS OF INCOME AMONG COWPEA FARMERS IN BAMA LOCAL GOVERNMENT AREA OF BORNO STATE, NIGERIA.
}

\author{
P.V. KWAGHE* , A. IBRAHIM, AND E.A. MOJIRODE \\ (Received 5 May, 2009; Revision Accepted 3 July, 2009)
}

\begin{abstract}
The paper analyzed the socioeconomic determinants of income among cowpea farmers in Bama Local Government Area (LGA) of Borno State, Nigeria. Primary data were mainly used for the study. This was collected using structured questionnaires administered to 120 cowpea farmers sampled from six villages spread across the LGA. The study employed both descriptive and inferential statistics to analyze the data. The findings of the study revealed that about $78 \%$ of the respondents were males while $22 \%$ were females. Majority of the farmers $(63.3 \%)$ had formal education and $73.3 \%$ cultivated farm land of not more than 2 hectares. The regression analysis result indicated that the variables specified in the model explain $75 \%$ of the income generated by the cowpea farmers in the study area. Educational level, number of productive members per household, access to extension agents and years of farming experience were significantly and positively related to income of cowpea farmers. Major constraints reported by the cowpea farmers in the study area include high cost of inputs and inadequate storage facilities. Based on the results of the study, it was recommended that policy measures aimed at providing relevant training opportunities and education schemes to the farmers should be encouraged; further more, farmers should be encouraged to join or form cooperative societies to take advantage of economics of scale in purchasing inputs and also to obtain good price for their produce.
\end{abstract}

KEY WORDS: Socio-economic, Determinants, Income, Cowpea, Bama, Nigeria.

\section{INTRODUCTION}

Cowpea (Vigna unguiculata L. Wrap) commonly known as beans is a leguminous crop that contains high protein with low fat content. It is gradually replacing animal protein in the diet of farming and low income households in Nigeria due to the relative high price of animal protein (Binta and Undiandeye, 2004). In addition to its utilization as an important component of diet, many rural farmers derive other benefits from the cultivation of the crop. The crop being a leguminous crop helps fix Nitrogen and improve the nutrient status of the farmlands; hence it is an important rotation crop. The stover and the chaff from the threshed pods are also useful feeds to livestock. Though cowpea as stressed above is a food crop, most rural farmers in Nigeria and particularly the study area cultivate it as a cash crop and hence earn income from the sale of the product.

Considering the role of cowpea as a food and source of income to the farmers, there is the need to increase cowpea production to meet the growing demand due to population growth. However, studies have shown that the annual growth rate of cowpea has been fluctuating over the years. For instance, the growth rate was $3.99 \%$ in 1985 , increased to $9.68 \%$ in 1986 , and drastically declined to $3.25 \%$ in 2003 (CBN, 1994; CBN, 2001; and CBN, 2003). This implies that Nigerian cowpea farmers have to improve their cowpea productivity, not only to feed the growing population but to generate income from the sale of surpluses. This can only be achieved by improving the production efficiency of the scarce resources at the disposal of the farmers.

Albert (1991) observed that cowpea production can only be increased in Nigeria by addressing not only the efficiency of the inputs used, but also by addressing the socioeconomic characteristics of farmers that affects their productivity and income. Given this background, this study analysed the socioeconomic determinants of income among cowpea farmers in Bama LGA of Born State, Nigeria. This was done by looking at some specific objectives which involved the examination of the socioeconomic characteristics of the respondents, determination of the relationship between farmers' socioeconomic variables and their income and identification of major problems facing cowpea farmers in the study area.

\section{METHODOLOGY}

\section{The Study Area}

The study was carried out in Bama LGA which is one of the 27 LGAs of Borno State located in the North eastern corner of Nigeria. It is located in latitude $12^{\circ} 10^{\prime \prime}$ and $14^{\circ} 00$ " North and longitude $11^{\circ} 30^{\prime \prime}$ and $13^{0} 16^{\prime \prime}$ East. Bama LGA has an area of 6,176 square kilometers with two distinct climatic zones (Sudan Savannah and Sahel) with mean temperature of $30^{\circ} \mathrm{C}$, and mean annual rainfall of $500 \mathrm{~mm}$. These climatic conditions are favorable for the cultivation of the local cowpea varieties, hence, majority of the populace of the study area who are predominantly small scale farmers produce the crop.

P.V. Kwaghe*, Department of Agricultural Economics and Extension, University of Maiduguri, Nigeria.

A. Ibrahim, Department of Agricultural Economics and Extension, University of Maiduguri, Nigeria.

E.A. Mojirode, Department of Agricultural Economics and Extension, University of Maiduguri, Nigeria. 


\section{Sampling Techniques and Data Sources}

A multistage sampling technique was used for selecting the representative cowpea farmers that were used for the study. The first stage was, therefore the purposive selection of three districts noted for cowpea production. The second stage involved selection of four villages, based on their sizes (not less than 50 households). The third stage was the random selection of 10 cowpea farmers from each of the 12 villages, giving a total of 120 cowpea farmers which were then used as respondents from which data were generated.

Primary data were mainly used for this study. These were generated from the cowpea farmers through the use of pre-tested, well-structured questionnaires administered by trained enumerators under the supervision of the researcher. Information on farmers socioeconomic characteristics, income from cowpea, and problems facing cowpea farmers were among the bulk of data collected. Secondary data were also used for the study. These were generated from publications and records of national and international organizations.

\section{Data Analysis}

Data were analysed using descriptive statistics and multiple regressions. The descriptive statistics used include frequency distribution, mean, and percentages. These were used to describe the socio-economic characteristics of the sampled farmers.

Among the functional forms fitted (Linear, Semilog, Double log, and Exponential) to determine the relationship between the socio-economic characteristics of the farmers and income from cowpea, the linear function gave the best fit and was chosen as the lead equation. The selection was based on the value of the coefficient of determination, the statistical significance of regression coefficients and correctness of signs of the regression coefficients. The empirical linear model used was specified as follows:

$Y=b_{0}+b_{1} x_{1}+b_{2} x_{2}+b_{3} x_{3}+b_{4} x_{4}+b_{5} x_{5}+b_{6} x_{6}+e .(1)$

Where: $Y=$ Income from sales of cowpea in

\begin{tabular}{|c|c|c|}
\hline & & Naira \\
\hline$x_{1}$ & $=$ & Years of formal educati \\
\hline$x_{2}$ & $=$ & Years of farming experi \\
\hline$x_{3}$ & $=$ & $\begin{array}{l}\text { Number of productive } \\
\text { of the household }\end{array}$ \\
\hline$X_{4}$ & $=$ & $\begin{array}{l}\text { Number of access to } \\
\text { services per season }\end{array}$ \\
\hline$x_{5}$ & $=$ & Labour cost in Naira \\
\hline$x_{6}$ & $=$ & Agricultural loan in Nair \\
\hline 0 & $=$ & Error term \\
\hline
\end{tabular}

\section{RESULTS AND DISCUSSION}

\section{Socio-economic Characteristics of Respondents}

The socio-economic characteristics of the cowpea farmers considered for this study were identified as important variables that influence farmers' income as also expressed by Ayende et al., (2005). The summary of the descriptive analyses of some of the socioeconomic characteristics of the cowpea farmers are as presented in Table 1.

Table 1: Distribution of Respondents by some Socio-economic Characteristics.

\begin{tabular}{lcc}
\hline Socioeconomic characteristic & Frequency $^{\mathbf{n}}$ & Percentage $^{*}$ \\
\hline Sex & 94 & \\
Male & 26 & 78.3 \\
Female & & 21.7 \\
Age (years) & 10 & 08.3 \\
Less than 20 years & 26 & 21.7 \\
$21-30$ & 48 & 40.0 \\
$31-40$ & 30 & 25.0 \\
$41-50$ & 6 & 05.0 \\
51 and above & & \\
Years of Farming Experience & 34 & 28.4 \\
$1-5$ & 38 & 31.6 \\
$6-10$ & 22 & 18.3 \\
$11-15$ & 26 & 21.4 \\
16 and above & & \\
Farm Size in Hectares & 58 & 48.3 \\
Less than 1 & 42 & 35.0 \\
$1-2$ & 20 & 16.7 \\
Above 2 & & \\
Educational Attainment & 44 & 36.7 \\
No formal education & 36 & 30.0 \\
Primary education & 28 & 23.0 \\
Secondary education & 12 & 10.0 \\
Tertiary & & \\
\hline
\end{tabular}

$n=120 ; \quad *=100 \%$ total. 
Gender of a farmer is important in agriculture because it determines the type of activity that can be undertaken by a farmer. Several studies have shown that adult male farmer carryout agricultural activities that are labour demanding, while female farmer carryout less labour demanding activities such as transportation and winnowing (Kwaghe, 1999 and Ani, 2004). The distribution of respondents in the study area indicated that majority of the respondents $(78.3 \%)$ were males, while only $21 \%$ were females.

The findings of this study shows that majority of the respondents $(61.7 \%)$ in the study area are those within the age bracket of 20 - 40 years. This reveals that majority of the cowpea farmers are in their youthful age. It has been observed that age of a farmer has an effect on the agricultural activities he or she can perform. For instance, in family labour, younger farmers spend much time on the farm and they embark on more strenuous farm operations than older farmers and children.

Entries from Table 1 also indicated that about $72 \%$ of the respondents have farming experiences of above 6 years. This shows that most of the farmers are experienced. According to Kwaghe (2006) farmers with many years of farming experience are more willing to change, especially to adopt current and recommended practices by extension agents.

Educational levels of farmers play a vital role in terms of adopting a new agricultural innovation and in general handling of farming activities. The result presented in Table 1 reveals that about $37 \%$ of the respondents had no formal education while the remaining $63 \%$ had a minimum of primary education. The significance of education was reported by Amaza (2000), who stressed that the level of education (years of schooling) helps farmers to use production information efficiently, as a more educated person acquires more information and to that extent, is a better producer. According to him such farmers will tend to have relatively better output and income.

Majority of the respondents representing $48.3 \%$ had farm size of less than 1.0 hectares, while only $16.7 \%$ of the respondents had farm size of above 2 hectares. According to Ibrahim (2004), small scale farmers are those farmers that cultivate land not more than 2 hectares. This result therefore justifies that the cowpea farmers sampled for the study are really small scale farmers.

\section{Variables influencing Incomes of Farmers}

The linear multiple regression results are present in Table 2. It reveals that the socio-economic variables included in the model had their coefficients significant at $1 \%(P<0.01)$. Out of the 6 socioeconomic variables, 5 have positive coefficients while only one that is the cost of labour has negative coefficient. The coefficient of determination $\left(R^{2}\right)$ is 0.745 , thus indicating that the model was a good fit to the data

The coefficient of farming experience was significant and positively related to the income of the cowpea farmers. The significant and positive coefficient of farming experience means that the more years of farming experience a farmer has the more farm income he obtains. This is because farmers with many years of farming experience all things being equal stand a better chance of improving output which increases their income.

The coefficient of number of productive members per household is positively related to income and a significant variable affecting income generation among the farmers in the study area. This could be so, because household with many productive members will probably contribute to the extra labour requirement of farm operation resulting to increase in cowpea output as well as income.

Table 2: $\quad$ Results of Regression Analysis

\begin{tabular}{llll}
\hline Variable & $\begin{array}{l}\text { Regression } \\
\text { Coefficient }\end{array}$ & $\begin{array}{l}\text { Standard } \\
\text { error }\end{array}$ & T-value \\
\hline Farming experience & 0.635 & 0.032 & $19.844^{*}$ \\
Educational Level & 0.341 & 0.082 & $4^{*} .159^{*}$ \\
No. of productive members per household & 0.211 & 0.069 & $3.058^{*}$ \\
Access to extension agents & 0.461 & 0.133 & $3.466^{*}$ \\
Cost of labour & -0.585 & 0.093 & $-6.290^{*}$ \\
Agricultural loan & 0.423 & 0.043 & $9.837^{*}$ \\
Constant & 1.403 & & \\
$R^{2}$ & 0.745 & & \\
F-ratio & 74.012 & & \\
& & & \\
\hline
\end{tabular}

$=\quad$ Significant at $1 \%$ level

The coefficient of educational level is positive and statistically significant at $1 \%$. This means that farmers' level of cowpea output increases with the increase in the educational level of the farmers. Farmers with more years of formal education tend to be more efficient in cowpea production, because of their ability to acquire more knowledge and improved technology, leading to increase in output and income.
The results further reveal that the coefficient of access to extension agent is significant at $1 \%$. The significance could be as result of exposure to improve technology which resulted into increased output and income. Similarly, the coefficient of agricultural loan was positive and statistically significant at $1 \%$, indicating that an increase in agricultural loan will improve farmers' access to farm inputs which will increase their yields and income. The coefficient of costs of labour, however, was 
significant but has negative relationship with the income of the farmers. The negative coefficient reveals that increase in cost of labour reduces the net income accruing to farmers from the cowpea enterprise.

\section{Major Problems of the Cowpea Farmers}

The major problems facing the cowpea farmers in the study area as presented in Table 3 are high cost of inputs, inadequate storage facilities, financial problems, transportation, low output prices and inadequate extension services. High cost of inputs was ranked the most important problem of the cowpea farmers in the study area. High cost of fertilizer, labour, agro-chemical and seeds were the most pronounced as indicated by $70 \%$ of the respondents. Kwaghe (2006) stressed that farming households that have access to improved farming inputs such as high yielding varieties of seeds and planting materials, fertilizer, pesticide tend to have higher productivity per hectare.

Inadequate storage facilities was ranked second most important problem as indicated by $60 \%$ of the respondent. Because of the susceptible nature of cowpea, pest and insects destroy it either during production or in storage; hence a suitable storage facilities are required to extend the shelf life of the product.

Table 3: $\quad$ Major Problems Reported by the Cowpea Farmers

\begin{tabular}{lll}
\hline Problems & Rank $^{*}$ & Percentage $^{* *}$ \\
\hline High cost of inputs & 1 & 70 \\
Inadequate storage facilities & 2 & 60 \\
Transportation & 4 & 43 \\
Inadequate extension services & 6 & 25 \\
Access to financial assistance & 3 & 46 \\
Low producers price & 5 & 36
\end{tabular}

\footnotetext{
* Order of magnitude

** $\quad$ Multiple responses exist, hence total exceeds $100 \%$
}

Other problems enumerated by the farmers are lack of financial support, transport related problems and low producer prices. The study discovered that financial assistance purposely designed for farmers are available but farmers are not aware of their existence or where they are aware, they lack knowledge to access the finances. With regards to transportation, the major problem is bad roads linking their communities and farm lands. Their gains are marred by the high cost of transportation which increases the cost of production and reduces the profits available to them. Low producers price is also one of the problems mentioned by the farmers. The study observed that because of the disadvantaged position (lack of storage facilities, lack of market information, poor bargaining power, etc), the middlemen who are more informed and organized gain more from the produce than the producers. Poor extension service is also one of the problems indicated by the respondents. This is justified by the existence and magnitude of the problems mentioned above. If extension services were adequate, it could have proffered solutions to minimize the effects of problems such as high input prices, lack of financial support, inadequate storage facilities, and low producer prices.

\section{CONCLUSION AND RECOMMENDATIONS}

Given the spectrum of the descriptive statistics and the multiple regression results, it is evident from the study that there is a convincing relationship between the socio-economic characteristics of the cowpea farmers and the income accruing from the sale of the cowpea. The study opined that cowpea farmers' income can be improved with improvement in their educational level, more access to extension services, and more number of productive members of household. Farmers' income can also receive further boost if some of the major problems facing cowpea farmers in the study area are addressed.

Based on the findings of this study, the following policy measures aimed at improving the income of cowpea farmers in the study area were recommended. This study showed that farmers' income increases with the increase in the level of education. It is observed that improvement in the farmers' income in the long run is not likely to achieve more success without major investment in human capital. Therefore, policy measures aimed at providing relevant training opportunities and education schemes to the farmers should be encouraged. It also recommended that farmers should form cooperatives organizations to take advantage of the economies of scale in purchasing inputs as well as bulking their produce for sale where prices are good. This will ensure reduced cost of production and reasonable prices to farmers.

\section{REFERENCES}

Albert, H. G., 1991. Economic Analysis of Cowpea Production in Jalingo Local Government Area of Taraba State, Nigeria. Unpublished B.Sc. Thesis, Department of Agricultural Economics and Extension, Federal University of Technology, Yola, Nigeria.

Amaza, P. S., 2000. Resource-use Efficiency in Food Crop Production in Gombe State, Nigeria. Ph.D. Thesis, Department of Agricultural Economics, University of Ibadan, Nigeria. 187pp.

Ani, A. O., 2004. Women in Agriculture and Rural Development. First Edition, Priscaquila Publishers. 
Ayende, I. A., Ashaolu, O. F., Adewuyi, A. A., and Agbonladhor, M. U., 2005. Analysis of Production of "Fifu" in Ibadan North Local Government Area of Oyo State, Nigeria. Proceedings of the Farm Management Association of Nigeria (FAMAN) $19^{\text {th }}$ Annual Conference.

Binta, A. Z. and Undiandeye, U. C., 2004. An Analysis of Price Fluctuation of Cowpea in Maiduguri Metropolitan, Borno State, Nigeria". International Journal of Food and Agricultural Research, 1, (1\&2): 22-30.

Central Bank of Nigeria., 1994. Statistical Bulletin, December.

Central Bank of Nigeria., 2001. Statistical Bulletin, December.

Central Bank of Nigeria., 2003. Statistical Bulletin, December.
Kwaghe, P.V., 1999. Women Feed the World: Prospects, Problems and Solutions for Sustainable Agriculture. In: Sustainable Agricultural Development: Principles and case Studies in Nigeria. Edited by U.C. Undiandeye, Y. Bila and S. Kushwaha. Mainasara Publishers, Maiduguri, Nigeria., 86-98.

Kwaghe, P. V., 2006. Poverty Profile and its Determinants among Farming Households in Borno State, Nigeria. Ph.D. Thesis, Department of Agricultural Economics and Extension, University of Maiduguri, Nigeria. 157pp.

Ibrahim, A., 2004. Analysis of Production Efficiency of Yam Production in Northern Part of Taraba State, Nigeria. M.Sc. dissertation, Department of Agricultural Economics and Extension, University of Maiduguri, Borno State, Nigeria. $76 p p$. 